\title{
THE EFFECT OF WORD PROCESSING APPLICATIONS FOR IMPROVING DEAF CHILDREN'S SPELLING ABILITY IN ELEMENTRY SCHOOL
}

\author{
Rifnurrohma AQ ${ }^{a}$, Mohammad Efendi ${ }^{b}$, Henry Praherdhiono \\ ${ }^{a b c}$ Department of Special Education, State University of Malang, Indonesia \\ Email: keykay6@gmail.com
}

\begin{abstract}
This study aimed to determine the effect of word processing application on learning outcomes spelling ability $p$ there is a deaf child in primary school. The research is a quantitative research, with this type of research Pre-Experimental with One-Group Pre-test Post-test Design, the subject of research amounted to 4 people . Based on the hypothesis testing results obtained $10.98>3182$, so there is a significant influence on the use of a word processing application on spelling ability in deaf children.
\end{abstract}

Keywords: word processing application, deaf children, spelling

The views language as a representation of the prowess of man according to Kravchenko (2016) affect cognitive development by forming human ecology. The ability of language contributes to social behavior. Language becomes a symbol used individually or in groups to interact. Language becomes a link that can be used to obtain information, messages and instructions to get the science. Language is derived from the capture process information, understanding up in expressing thoughts, and all intertwined with the process of communicating to humans (Efendi, 2013). In general, the ecological discuss a involved in language processing, control of linguistic and non-linguistic control can be done by a word processor Coderre (2016).

Children with hearing impairment have communication problems that have an impact on language skills, reading, writing, socializing and achievement in school (Efendi, 2016). Communication problems due to interference ketunarunguan difficult to identify early on. This is caused by the all babies, including a baby deaf since birth will use their voice. But not the only aspect that will be affected, but all aspects of development and the lives of deaf children are affected (Mangunsong, 2009).

Barriers experienced by children with hearing allows them difficult to understand the meaning of words, so that deaf children are often referred to as a boy who "poor language" (Effendi, 2016) . Terhambatnya speech and language development of deaf children become a problem early is great, due to the development of language and speech for someone has $a$ vital role. Because $b$ ahasa is the main means of communication and means of thinking, so the ability of a person depends on his intelligence language. On hearing the child can acquire and imitate message language directly through the sense of hearing so that vocabulary can be easily interpreted. In contrast to a deaf child who said the acquisition is only obtained from the visual senses through the lips, gestures and body language of the speaker (Kirk et al, 2016). Visual senses serve as the receiver of information that can be seen and observed, but lack the visual senses are limited.

The ability to read and write deaf children in the early grades need to be strengthened. If learning literacy (reading and writing) at the beginning of class is not strong, then at the stage of reading and writing about the child will have difficulties to be able to have the ability to read and write adequately. The purpose of reading and writing the beginning is that the child can recognize handwriting as an emblem or symbol language, so that children can speak the text. Reading skills acquired at the beginning of the reading will greatly affect the ability to read further. As the capabilities that underlie the ability of the next, beginning reading skills need attention. The ability to write starters are not much different from the ability to read the beginning. At a basic level, learning to write more oriented towards the mechanical capabilities (Mulyati, 2012). Writing skills is one of the daily language skills that are productive. Learning writing includes writing, spelling (pronounce the letters one by one) and fabricated. In the lower classes, deaf children are still using oral or spoken language. Oral language one of which teach children to spell because it plays an important role in understanding a conversation with someone and the other person's lips. Barriers experienced by children with hearing impairment in language enables children difficult to understand the meaning of words (Effendi, 2009). Hearing loss has negative effects on different levels of reading comprehension (Sharifi, Kakojoibari, Sarmadi, 2011)., 
Researchers looked at the cases of second grade students in SDLB Putra Jaya Malang are having problems in the vocabulary. Children are able to write the alphabet $A$ to $Z$, but have difficulty reading of vowels and consonants. When observation is made, the child is still difficult to read vowels and consonants are assembled into a few words with pronunciations that are not so obvious. Students often indicate an error in working order had to be helped using finger gestures, such as the word " closet " was written with " lemri " and the letter $\mathbf{s}$ is written upside down. It shows if the level of mastery and understanding of the language is still low. They are less motivated than in the child or the child outside of the environment, the power of abstraction, memory, and the media were less varied vocabulary used in the formation. Need to use media that can assist in the learning process based on existing problems. Learning media is expected to facilitate teachers in presenting the material. Instructional media used should at least be visual media or even media that can involve all the senses that can provide the experience and understanding in children.

The development of computer technology has penetrated the entire community. Yaghoobi (2016) stated learning requires computer technology to improve reading skills . Computer-assisted learning technologies into a media and learning resources as well as media student interaction with teachers in learning. According to Goldenberg (2016) Technology computer-based learning can be applied to a particular application must go through the media. Komputer as a learning medium has a diversity of functions as needed. Thus, the use or development must consider several techniques that can be used as a maximum and in accordance with the objectives of the media. A pplications word processor is an application that can be used as a medium to foster a sense of enthusiasm and self-confidence in children in learning to spell. Through word processing application Fernández (2016) is a computer-based learning technology and technology visual media children are invited to hone the ability to spell it.

\section{METHOD}

This study used quantitative research with experimental research methods. According to Rubin (2016) of research data on a quantitative approach in the form of figures and statistical analysis using. According to Robson (2016) experimental research method is a way to find a causal connection between the two factors is intentionally inflicted by the researchers by eliminating other factors that interfere.

This study design using pre-experimental, while the form of the design used is one group pretestposttest design with one group of subjects (Arikunto,
2010:123-124). The first measurement, then subjected to treatment for a certain period and measurement for the second time. Subjects in this study is a deaf child class II, amounting to 4 people. The subject of research is the main source of research data that have data regarding the variables studied.

Measurement of spelling ability of deaf children is done by providing test questions read. Kids are asked to spell out the letters that appear on the screen. This test was conducted to determine the extent of the achievement and abilities of students in spelling every syllable that is the amount of matter as much as 10 pieces. After obtaining data from the pretest and posttest, researchers process data using the $t$ test to compare two variables during the pre-test and posttest. There are two different results can be used to see how much influence a word processing application (Microsoft Office Word) to spelling ability of deaf children.

\section{FINDINGS AND DISCUSSION}

\section{Findings}

This research uses experimental research to determine the effect of using a word processing application on the ability to spell and the study design used is one group pret-test-post-test design. In the design of one group pret-test-post-test design, only experiments performed on one group and obtained two kinds of data . Two of these data is the ability to start and end the ability of learners in spelling. D ata initial ability learners is data that has not been treated as a test to determine the extent of the initial capabilities of learners (pre-test). While final data is data obtained by researchers after treated (treatment) with the administration of the test (post-test).

Pre-test done before being given treatment or treatment by using a word processing application and after treatment by using a word processor, then do the post-test one. Here is a table of the comparison of the value of the pre-test and post-test were visible difference in the time before and after treated by using a word processing application.

Table 1. Comparison Value Pre-test and Post-test

\begin{tabular}{|c|c|c|c|c|}
\hline No. & Subject & $\begin{array}{c}\text { value } \\
\text { Pretest }\end{array}$ & $\begin{array}{c}\text { value } \\
\text { posttest }\end{array}$ & $\begin{array}{c}\text { Changes } \\
\text { Alerts }\end{array}$ \\
\hline 1 & de & 50 & 80 & + \\
\hline 2 & In & 65 & 85 & + \\
\hline 3 & $\mathrm{Fa}$ & 20 & 50 & + \\
\hline 4 & $\mathrm{Wi}$ & 25 & 50 & + \\
\hline \multicolumn{2}{|c|}{ Amount } & 150 & 265 & \\
\hline \multicolumn{2}{|c|}{ Average } & 37.5 & 66.25 & \\
\hline
\end{tabular}


Here is a graph of the results comparison of the pre-test and post-test that looks the difference before and after treated by using a word processing application.

From the data presented it can be concluded that the average value of the pre-test is lower than the value of the average post-test. That difference shows that there are differences in spelling ability after being treated using a word processing application that showed an increase.

Here is a table of the value of the test statistic difference between paired observations

Table 2. Value Average Difference Between Observation Couples

\begin{tabular}{|c|c|c|c|c|c|c|}
\hline \multirow[t]{2}{*}{ No. } & \multirow[t]{2}{*}{ Name } & \multicolumn{2}{|c|}{ Value } & \multirow{2}{*}{$\begin{array}{c}\text { change } \\
\text { sign }\end{array}$} & \multirow{2}{*}{$\begin{array}{c}\mathrm{d} \\
\left(\mathrm{X}_{1}-\mathrm{X}_{2}\right)\end{array}$} & \multirow[t]{2}{*}{$d^{2}$} \\
\hline & & $\begin{array}{l}\text { Pre- } \\
\text { test }\end{array}$ & \begin{tabular}{|l} 
Post- \\
test
\end{tabular} & & & \\
\hline 1 & de & 50 & 80 & + & -30 & 900 \\
\hline 2 & In & 65 & 85 & + & -20 & 400 \\
\hline 3 & $\mathrm{Fa}$ & 20 & 50 & + & -30 & 900 \\
\hline 4 & $\mathrm{Wi}$ & 25 & 50 & + & -25 & 625 \\
\hline \multicolumn{2}{|c|}{ Amount } & 150 & 265 & & -105 & 2825 \\
\hline \multicolumn{2}{|c|}{ Average } & 37.5 & 66.25 & & & \\
\hline
\end{tabular}

By using the $\mathrm{t}$ test first seek standard deviation formula $\mathrm{sd}=4.78$. Once the standard deviation is obtained, then look for the value of $t$ by the formula $\mathrm{t}=10.98$. Furthermore, to test hypotheses with tables $\mathrm{t} \operatorname{sig} \alpha=0.05$ with degrees of freedom $(\mathrm{df}=\mathrm{n}-1) 3$, then the results obtained table $=3.182$. Based on the $\mathrm{t}$ value will be the result $\mathrm{H}_{0}$ is rejected if $\mathrm{t}$ count $>\mathrm{t}$ table and $\mathrm{H}_{1}$ accepted if the value of $\mathrm{t}<\mathrm{t}$ table of values. This research has resulted in findings $t>$ $\mathrm{t}$ table with a par $10,98>3.182$ it can be concluded $\mathrm{H}_{0}$ is rejected and $\mathrm{H}_{1}$ accepted, which means a word processing application ( Microsoft Office Word) affect the spelling ability of deaf children.

\section{Discussion}

Spelling ability Deaf Children Before Using Word Processing Applications

Learning activities in research conducted in SDLB PUTRA JAYA Malang with a number of subjects as 4 . In the study, researchers act as implementers of learning. The first stage the researchers did was conduct a test or a so-called pre-test yangberfungsi the ability to see the start of the subjects studied. Researchers gave about as much as the 10 points which can then be given a value based on the correct answer. Every problem is worth ten and for the wrong answer is zero so that the maximum score is 100 .

The pre-test is obtained and then averaged and the results obtained 37.5. The results can be categorized as low. Visible in the process, students often confusion in spelling out the letters or syllables. According Bogdashina (2016) the development of speech and language of deaf children is hampered due to the sharpness of his hearing less than a child hears. In the process of babble does not happen impersonation and confined to the visual imitation.

Efendi (2009) and El-Maksoud (2016) states that a deaf child who receives everything recorded through visual perception tends to poor vocabulary, difficult to interpret language expression containing a figurative sense, the difficulty in interpreting the words abstract and difficult to master the rhythm and style language.

After Deaf Children's ability Spelling Using Word Processing Applications

II class learning activities SDLB PUTRA JAYA Malang at the stage of post-test was also attended by 4 pupils. The questions in the post-test is also the same as a matter that was made at the pre-test. Phase posttest carried out after the treatment (treatment) in children with hearing impairment in the ability to spell using word processing applications. Deaf children have a vocabulary is inadequate to express his experience and understanding of syntax that are less experienced. The impact caused deafness deaf children have difficulty in expressing his language both verbally and nonverbally. According Riasnelly (2013) the use of ICT is one of the media in the learning strategies that lead to the ability of educators to understand the technology on the one hand, on the other hand utilize tekonologi progress as one of the media that will provide convenience. The final result after treated ( treatment) on the spelling ability of deaf children in SDLB PUTRA JAYA Malang using word processing applications has increased. This is indicated by the average value of the current posttest which rose to 66.25 .

The Effect of Word Processing Applications for Improving Deaf Children's Spelling Ability in Elementry School

In the world of education today began using the technology in various aspects included in the learning activities in order to be able to prepare human resources who are ready to face global challenges in the utilization of information technology. In the speech and language of deaf children need guidance and training in particular. The ability to read is the ability to understand the information conveyed others through writing, so as to live in a modern technological society one must be literate.

The use of a word processing application on a deaf child has an influence on the ability to spell. The effect of using a word processing application is evidenced by the difference value results in pre-test and post-test. In the pre-test is obtained an average value of 37.5 , while in post-test values obtained an average of 66.25 , which 
means there is an increase indicated the students'spelling ability at 28.75 on the prior use of a word processing application and thereafter, Several studies (Weiss, 2016; Lai , 2016 ; Ghadirli , 2016; Chauhan , 2017 ; Byers , 2016) showed that the effectiveness of learning by using better technology compared to traditional or conventional learning. Rusman research results in 2006 showed the results of learning by using computer-based learning model of tutorial and drill and practice is far better than conventional learning (Idris, 2015: 176). Drill and Practice learning method is a technique of teaching is done repeatedly to get the skills, needed to remember mathematically. This method is used to teach special skills, this is followed by a systematic teaching in the hope to remember (Richardson, 2006: www.cornerstonecurriculum. com). Methods Drill and Practice is usually used in a matter of learning materials, foreign language and increase vocabulary (vocabulary). Methods Drill and Practice directs students through exercises to improve dexterity / dexterity and proficiency / fluency in a skill (Sharon, 2005:120; Thornbury, 2016 ).

Kendala research is one of the research subjects did not follow the learning activities and overdue at the time of treatment took place. However, all the students enthusiastically participated in the study by using a word processing application so that the material can be conveyed and have an influence on students' spelling ability after the post-test done.

\section{CONCLUSION AND SUGGESTION}

Spelling ability of deaf children class II on the pretest are still classified low with average values of 37.5 and the post-test were classified simply by the average value of 66.25 . As well as on the hypothesis test, the result $\mathrm{H}_{0}$ is rejected because the value $\mathrm{t}$ is greater than $\mathrm{t}$ table. So it can be concluded that there is significant influence between spelling ability before using a word processing application after application with a word processing application.

A word processor is a computer-based learning media to improve learning spelling. So in theory a word processing application can be used as a medium that supports the learning activities to spell in school. So that teachers of children with special needs can optimize the learning activities in the context of language, spelling and reading using a word processing application.

\section{REFERENCES}

Arikunto, S. 2010 . Procedure Research (A Practical Approach). Jakarta: Rineka Reserved

Byers, T., Hartnell - Young, E. and IMMS, W., 2016. Empirical evaluation of different classroom spaces on students' perceptions of the use and effectiveness of one - to - one technology. British Journal of Educational Technology .

Bogdashina, O. 2016. Sensory perceptual issues in autism and Asperger syndrome: Different sensory perceptual experiences-different worlds. Jessica Kingsley Publishers.

Chauhan, S., 2017. A meta-analysis of the impact of technology on learning effectiveness of elementary students. Computers \& Education, 105 , pp.14-30.

Coderre, EL, Smith, JF, Van Heuven, WJ and Horwitz, B., 2016. The functional overlap of executive control and language processing in bilinguals. Bilingualism: Language and Cognition , 19 (03), pp.471-488.

Efendi, M. 2009. Introduction Psikopedagogik children with disabilities .Jakarta: PT. earth Literacy

Efendi, M. 2016. Psikopedagogik Children with special needs. Malang: The Malang State universities.

Fernández, G., Sapognikoff, M., Guinjoan, S., Orozco, D. and Agamennoni, O., 2016. Word processing during reading sentences in Patients with schizophrenia: Evidences from Eyetracking technique. Comprehensive Psychiatry, 68, pp.193-200

Ghadirli, HM, Rastgarpour, M., Hashemi, SM and Pedram, MM, 2016. Effectiveness of Learning Style in Popularity of Personalized Mobile Intelligent Tutoring System from View of Learners. Indian Journal of Science and Technology, 9 (31).

Goldenberg, L., 2016. Socio-Cultural Effects of Integrating Multimedia into the General English. Impact of Information Technology: From practice to curriculum, p.143

Idris. 2015. Jurnal Potensia. The effectiveness of the use of Information and Communication Technology in the Islamic Religious Education Learning .14 (2), (Online), http://ejournal. uinsuska.ac.id/ index.php/potensia/article/download/1449/1243 , accessed on 18 February 2016

Lai, C., Shum, M. and Tian, Y., 2016. Enhancing learners' self-directed use of technology for language learning: the effectiveness of an online training platform. Computer Assisted Language Learning , 29 (1), pp.40-60. 
Kirk, S.A, Gallagher, J.J. colemen, M.R. Anastasiow, N. (2009). Educating Exceptional children । Boston: Hougton Mifflin Hareorent Publishing company

Kravchenko, AV. 2016. Language as human ecology: a new agenda for linguistic education. New Ideas in Psychology, 42 , pp.14-20.

Mangunsong, Frida. 2009. Psychology and Education Children with Special Needs .Depok: LPSP3 UI

Mulyati. 2012. Reading and Writing Learning Module Startup. Bandung: FBS UPI

Riasnelly. 2013. E-JUPEKhu. Effectiveness of Using Media Information and Communication Technology (ICT) in Developing Ability in Children Deaf Sentence in Tanjungpinang SDLB .1 (2), (Online) http://ejournal. unp.ac.id/index.php/ jupekhu, accessed on 18 February 2016
Robson, C. and McCartan, K., 2016. Real world research. John Wiley \& Sons.

Rubin, A. and Babbie, ER, 2016. Empowerment Series: Research Methods for Social Work . Cengage Learning.

Sharifi, A., Kakojoibari, AA, Sarmadi, MR (2011). Comparison of Different Levels of Reading Comprehension between Hearing-Impaired Hearing loss and Normal Students. Audiology, 2011; 19 (2): 25-32.

Yaghoobi, M. and Razmjoo, SA, 2016. The potentiality of computer-assisted instruction towards ameliorating Iranian EFL learners' reading levels. Computers in Human Behavior, 59 , pp.108-114.

Weiss, CT, 2016. Effectiveness of 1: 1 technology in the science classroom. 